\title{
White, yellow and green pigments on Polish artists' palettes in the period $1838-1938$
}

\author{
Mirosław Wachowiak $^{1 \star}$, Grzegorz Trykowski ${ }^{2}$, Iwona Żmuda-Trzebiatowska ${ }^{3}$ \\ 1 Department of Conservation and Restoration of Modern Art, Nicolaus Copernicus University, \\ Gagarina 11, 87-100 Toruń, Poland \\ 2 Instrumental Analysis Department, Faculty of Chemistry, Nicolaus Copernicus University, Gagarina \\ 11, 87-100 Toruń, Poland \\ 3 Photophysics Department, The Szewalski Institute, Polish Academy of Sciences, Fiszera 14, 80-231 \\ Gdańsk, Poland \\ * Corresponding author: miroszwach@wp.pl
}

\begin{abstract}
In the $19^{\text {th }}$ century, the evolution of white, yellow and other pigments was forced by numerous chemical discoveries. Dates of their inventions and patents, despite being well established in the literature, are not consistent with time of their implementation by painters. The survey of more than 300 hundred Polish artists' paintings from the period 1838-1938 confirmed this observation. The reported research allowed building chronological database of the first use, periods of intensive exploitation and of the decline of use or absence of specific pigments in the Polish artists' studio practice.

Portable XRF examination, Raman spectroscopy and SEM-EDX analysis enabled establishing dates of first applications of zinc white, chrome yellow, cadmium yellow, strontium yellow, zinc yellow, emerald green and viridian on paintings. Moreover, the research showed modifications of Naples yellow by zinc- or tin-based admixtures in the second half of the $19^{\text {th }}$ century as well as evolution of additives to basic lead white such as earth pigments, chalk, barites, zinc white or lithopone. The accuracy of dating and authentication of the artworks analysed was strengthened by examination of composition of their grounds. In some cases individual habits of artists of using special kinds of primings or characteristic pigments were revealed giving a support for authentication studies. The data gathered in this research proved to be a reliable basis for attribution and dating of paintings of uncertain origin.
\end{abstract}

Keywords: $19^{\text {th }}$ century pigments, Raman spectrometry, authentication, painting technology, non-invasive analyses, XRF portable spectrometry, J. Matejko, J. Pankiewicz

\section{Introduction}

As in the $19^{\text {th }}$ century numerous new pigments were introduced onto artists' palettes, their identification provides significant information on the artists' studio practice. Sufficient number of investigated paintings enables statistical conclusions based on pigments' identification, supporting dating authentication and in some cases, attribution of paintings. To a noticeable degree, it is possible also for the works from the first half on the $20^{\text {th }}$ century when subsequent synthetic pigments were introduced [1]. 
The preliminary data on non-organic pigments in a non-invasive way was collected by XRF examinations with portable instruments $[2,3]$. When sampling was possible, Raman spectroscopy, SEM-EDX and in some cases $\mathrm{XRD}$ were additionally used.

The number of objects examined exceeds three hundred items. Paintings originated from collections of the District Museum in Toruń, National Museum in Poznań, National Museum in Kraków and National Museum in Warsaw. There were also a few works from a private collection and the auction market; however, the core of the studied paintings were museum objects dated with certainty. The analysed period 1838-1938 starts with the first identified presence of a significant amount of barites and comes to an end a century later, time of preliminary, but still rare introduction of titanium white.

Whites were chosen as representative pigments because they were used on every painting and their chemical composition evolved significantly during $19^{\text {th }}$ and $20^{\text {th }}$ centuries. It is also easy to identify the pigments with the use of simple XRF examination. Moreover, white pigments are also present in grounds, which were investigated as well. The latter can give more systematic chronological data, especially in case of factory-made priming's offered on the market, as they were less susceptible to subjective artists' choices $[4,5]$. When both pigments and primings' fillers are identified, the chronological results are significantly more reliable than just pigments' examination considered alone [6].

The other group of pigments - yellows - is also present on nearly every painting and some significant continuous changes of chemical composition, taking place over the course of both centuries, are to be observed.
While investigating yellows it is also necessary to consider greens, to which they were commonly added.

The aim of the conducted research was to present a panorama of evolution of chemical composition and the use of white, yellow and green pigments from the $19^{\text {th }}$ to $20^{\text {th }}$ centuries, to display possible changes in time within certain kinds of pigments, trace some individual artists' habits and check to what extent the non-invasive portable XRF analysis is sufficient for such undertaking. The number of non-invasive measurements possible to be conducted, regardless of some limits of the technique, enables collecting statistical results impossible to gain with destructive analyses that need sampling. Importantly enough, the technique is convenient and relatively simple to use also on site. On the other hand, especially when building a chronological database, it is necessary to include methods like Raman spectroscopy. For stratigraphy recognition of the cross-section of sample BSE imaging and SEM-EDX examinations may be feasible.

\section{Materials and methods}

Further research was preceded by the observation of the UV excited fluorescence of the painting in order to avoid testing of non-original parts. The research methodology was to start with the identification of elemental composition of different areas of the paintings related to different colours with the portable XRF spectrometer. When sampling was possible, complementary Raman spectroscopy and SEM-EDX analysis was used for the identification of pigments ambiguous to detect, basing on the XRF examination only. 


\subsection{XRF}

The portable XRF spectrometer used in this study was the Genius 7000 from Skyray Instruments, equipped with the Ag lamp as a source of radiation, working at $40 \mathrm{kV} / 100$ $\mu \mathrm{A}$ conditions and a SDD detector. The instrument allows for detection of elements from magnesium to uranium. The time of a single measurement was $120 \mathrm{~s}$. The instrument was factory-optimised for pigments identification. The optimisation was based on the preceding analyses of historical-like model samples of paints of known composition.

In order to get data as reliable as possible, the measurements were repeated over a given area to avoid false identification from local contaminations. Since $\mathrm{X}$ rays penetrate the painting deeply enough to get fluorescence signal not only from the paint layer but from the priming as well, identification of pigments in the paint layer was preceded by the examination of priming itself. The latter was performed on tacking margins or from the back side of the paintings. In the case of pigments present in mixtures and/or in many layers the reliability of results was increased by collecting data along linear path over the area of the same hue but with gradually changed saturation and tonality. The reasonably stable ratio of intensities of lines of key elements indicated the use of factory-made paint only mixed with different amount of white to obtain desired saturation and tonality. As an example of such a procedure, the distinguishing between a viridian and a green paint made of chrome yellow mixed by artist with blues may be given. In the case of doubts additional examination with Raman spectroscopy [7] and SEM-EDX was used.

\subsection{Raman spectroscopy}

The Raman spectra were acquired by means of the InVia $\mu$-Raman spectrometer from Renishaw Group equipped with two lasers providing excitations at 785 and 514 $\mathrm{nm}$. The confocal microscope with objectives of magnification of 20,50 and $100 \times$ assured the spectral footprint of the sample surface area down to about $5 \times 5 \mu \mathrm{m}^{2}$. For dispersion of the backscattered signal, the grating of 1200 groves $/ \mathrm{mm}$ was used and detection was provided by a CCD array detector.

The spectrometer calibration was performed with the use of the polystyrene standard. Spectra were acquired over the range of $100-3200 \mathrm{~cm}^{-1}$ at resolution of $2 \mathrm{~cm}^{-1}$. Depending on the signal intensity up to 10 spectra of individual samples were accumulated and averaged. All spectra were processed and baseline corrected using the OriginLab $^{\odot}$ package. Pigments and paint components were identified basing on the reference spectra from digital Raman libraries [8-10]. It enabled not only the identification of pigments which were hardly distinguishable by XRF analysis, such as Scheele's green and emerald green or other chrome based pigments, but it also supported revealing the composition of mixtures of more than one colour [11].

\subsection{SEM-EDX}

Sample's cross-sections were observed with Scanning Electron Microscopy (SEM) technique using Scattered Electrons (SE) and Back SE imaging and examined with the Energy Dispersive X-ray (SEM-EDX) detector enabling elemental mapping. The instrument used was the SEM-LEO 1430VP microscope from Zeiss operated with BSE detector. The 
energy dispersive X-ray spectrometer (EDX) used in this research was Quantax 200 with XFlash 4010 from Bruker working at $28 \mathrm{kV}$ in variable pressure up to $50 \mathrm{~Pa}$.

\subsection{Objects}

Artists examined include the following names: Piotr Michałowski (1800-1855), Franciszek Kostrzewski (1826-1911), Józef Szementowski (1833-1876), Wojciech Gerson (1831-1901), Władysław Malecki (1836-1900), Jan Matejko (1838-1893), Witold Pruszkowski (1846-1896), Józef Chełmoński (1849-1914), Leon Wyczółkowski (1852-1936), Jacek Malczewski (1854-1929), Stanisław Lentz (1861-1920), Józef Pankiewicz (1866-1940), Stanisław Wyspiański (1869-1907), Józef Mehoffer (1869-1946), Wojciech Weiss (1875-1950), Fryderyk Pautsch (1877-1950), Władysław Jarocki (1879-1965), Stanisław Ignacy Witkiewicz (1885-1939), Vlastimil Hoffman (1881-1970) and Ludomir Ślendziński (1889-1980). Objects chosen were only of certain origin and dating mostly from museums, some also from private collection, considering representation of each year between the period 1838-1938. Number of examined objects exceeded 300 , enabled to draw some statistical conclusions. In the case of Jan Matejko and Józef Pankiewicz, when number of investigated paintings exceeded 60 , revealing the evolution of the palettes within certain periods of their artistic lives was possible $[12,13]$.

\section{Results}

\subsection{Whites}

Main white of the $19^{\text {th }}$ century is the lead white, pigment popular since antiquity. Yet as early as the end of the $18^{\text {th }}$ century, some alternatives were introduced - one of them was barium sulphate suggested for use as pigment in 1782. It could originate from the natural ores or could be synthesized and then was sold under the name blanc fixe. Its more significant production did not start before 1810-1820, yet already in 1825 Leuch mentioned the adulteration of lead white by admixtures of barite and Kulmans manufacture started its production in 1830 [14]. According to the presented research (Fig. 1), the earliest Polish paintings where admixtures of barium sulphate to the lead white were detected are dated 1838. Zinc white was found as admixture to the lead white in painting from the following year, even though it had been suggested as the lead white alternative as early as at the end of the $18^{\text {th }}$ century. The amount of zinc white admixed to the lead white raises with time especially from the year 1855 on, yet it is as late as 1883 when the pure zinc white with no addition of lead white is detected on Polish painting. In the sixties, a complex mixtures of lead, zinc and barium white are found on the paintings. In all the cases, significant shifts in time were observed in comparison to the dates of commercial introduction suggested by literature and the ones confirmed during research. The biggest "gap" for the pure zinc white exceeds half of the century.

The research (Fig. 1a) brought not only information on the real points in time of the first appearances of pigments significantly differing from the ones found in literature, but it also provided details on their abundance. Lead white is present throughout all the century. Barium sulphate identified since 1838 as admixture to lead white is slightly less common but invariably popular through the century. In the fifties, the zinc white is added to the lead white quite often but only 

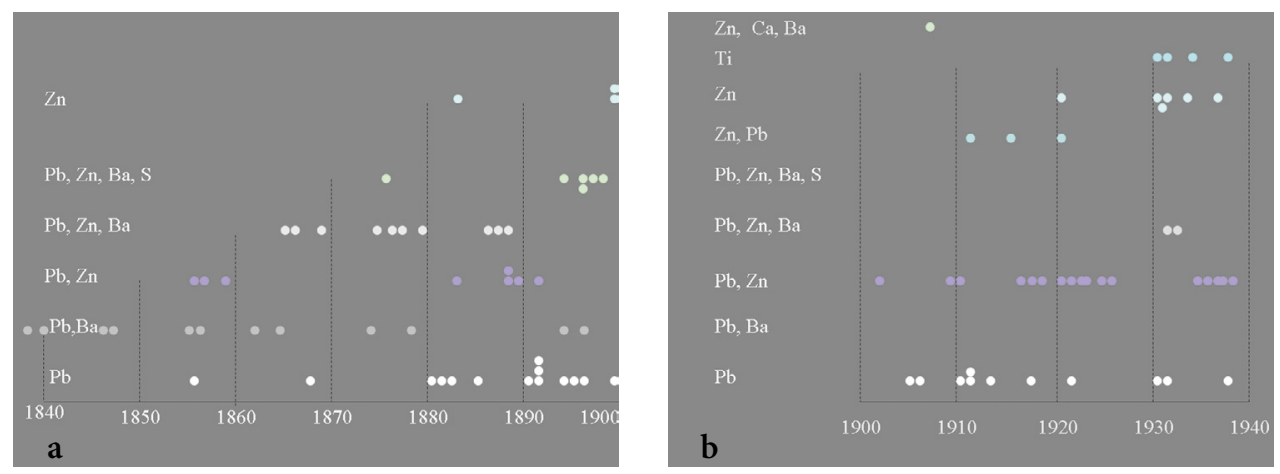

Fig. 1. Whites detected in paintings from a: $1838-1900$ period; b: $1901-1938$ period: lead white $(\mathrm{Pb})$, lead white with barium white $(\mathrm{Pb}, \mathrm{Ba})$, lead white with zinc white $(\mathrm{Pb}, \mathrm{Zn})$, zinc white with addition of lead white $(\mathrm{Zn}, \mathrm{Pb})$, pure zinc white $(\mathrm{Zn})$, titanium white mixtures $(\mathrm{Ti})$, mixture of lead and zinc and barium white $(\mathrm{Pb}$, $\mathrm{Zn}, \mathrm{Ba})$, zinc white admixed with chalk and barites ( $\mathrm{Zn}, \mathrm{Ca}, \mathrm{Ba})$, lithopone ( $\mathrm{Pb}, \mathrm{Zn}, \mathrm{Ba}, \mathrm{S})$, lead white admixed with chalk and barium white $(\mathrm{Pb}, \mathrm{Ca}, \mathrm{Ba})$.

for a short period, and seems to return again in this mixture some thirty years later. In the meantime, the three ingredient basing mixtures - lead, zinc and barium white - become popular between half of the sixties and half of the eighties, when it starts to decline to be used at all. As late as the beginning of the nineties, lithopone is added to the lead white.

As it is seen from Fig. 1b, titanium white was not used as pure pigment at least until the end of the Second World War. According to the written sources, the introduction of titanium white onto artists' palettes in a wider scale could take place in Europe about 1922 when so called Blumenfeld method was used for pigment production [15]. The present research revealed that in Poland it is present not earlier than in 1930, when titanium white is detected as minor admixtures to the zinc white in the Vilnius school compositions (with the zinc white as the main component and titanium white as relatively little admixture between 2-5\%) and in the case of other Polish painters even later - in the early thirties, as admixture to lead white and bar- ites. Another ingredient identified as added to the titanium white in a quite significant level - even in areas of pure white colour - is iron. It is possible, that the source - ilmenite - was not cleaned properly at the early stage of production [7]. In the case of Kazimierz Kwiatkowski, white paint being a mixture of zinc white and additions of titanium white is used on the same single painting (Portrait of Herta Dzikowska, from 1930) in parallel with the more traditional mixture of zinc white and lead white (Figs. 2-3).

In the painting of Ludomir Ślendziński from the next year, this zinc white (majority) and titanium white (minority) mixture is used as the only white. The example of painting of Edward Karniej from 1937 shows a mixture of zinc, lead white, chalk and titanium white. In the case of the Still life (1938, Silesian Museum in Katowice) by Józef Pankiewicz, white is the mixture that contains lead white, barites and titanium white. It is the first painting in artist's oeuvre in which the titanium white was detected. It seems that closer and more statistical recognition in the meaning of the number of paintings 


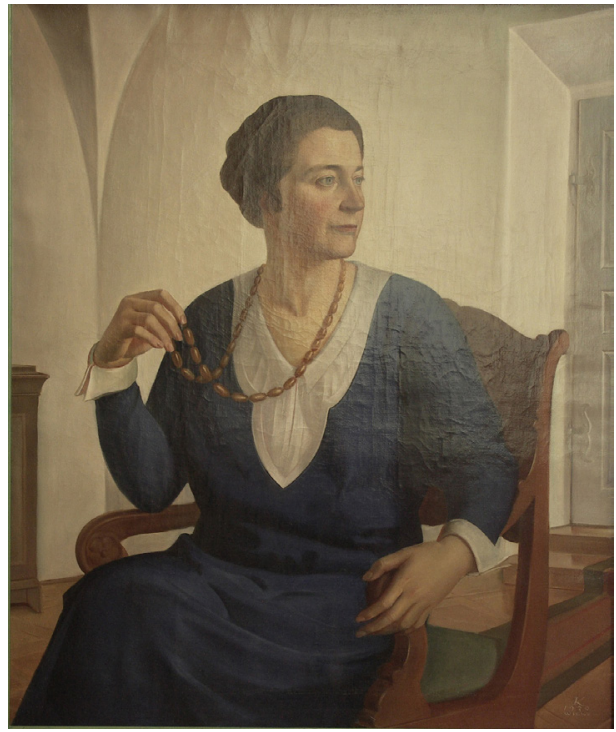

Fig. 2. Kazimierz Kwiatkowski, Portrait of Herta Dzikowska, 1930, District Museum in Torun. Both, traditional lead white and zinc white with titanium white admixed are used on the painting. Photo by M. Wachowiak. the Louis Nicholas Vauquelin researching crocoite, mineral found in Siberia [16]. The most important chromium containing yellow pigment - lead chromate - was identified on Polish paintings from the year 1836, nearly two decades after the first publication. Zinc chromate was detected on the painting from 1869 and for strontium chromate - on the one from 1874. As barium chromate was much more problematic in certain distinction from the barite or blanc fixe admixtures, no exact date was proposed for the moment of implementation by artists, yet it seems that in the 1880 s the pigment is already present on their palettes. Chromium yellows are common through all the second half of the $19^{\text {th }}$ century (Fig $4 a$ ).

Cadmium yellow was for the first time detected on the painting from 1861. Since its significance raises, in the seventies it is already common in use and in the eighties

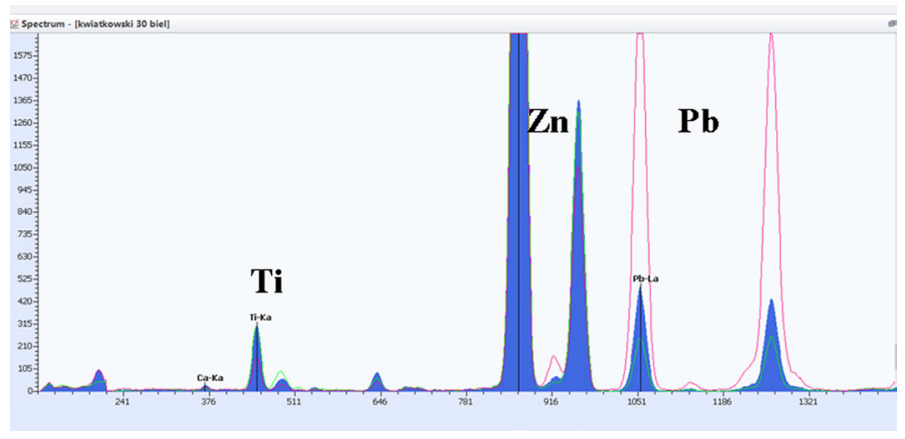

Fig. 3. XRF spectra of two whites: traditional lead white with zinc white (red line spectrum) and zinc white with admixture of titanium white (measured in two points: blue-filled spectrum and green line spectrum), detected on the painting by K. Kwiatkowski, Portrait of Herta Dzikowska, 1930.

examined can give further chronological, and maybe to some extent geographical, distinctions basing on ratios of the titanium and other whites included in complex white compositions of the 1930s and 1940s.

\subsection{Yellows}

A big group of yellows containing chromium were proposed as pigment in 1808-1809 by dominant. Cadmium yellow with significant addition of zinc is described in literature as popular one [17]. Basing only on non-invasive analyses, it is hard to say whether only metal zinc or its oxides or sulfides were added as well. Probably both cases took place. Interestingly enough, from the end of the $19^{\text {th }}$ century significant amount of potassium and aluminium appears as additional elements to cadmium (Figs. 5-6). 

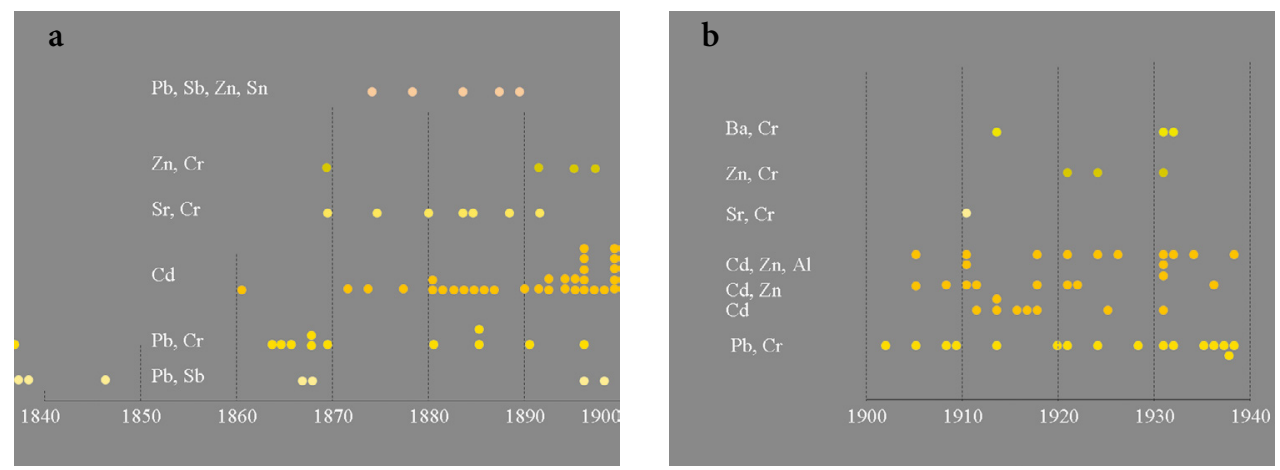

Fig. 4. Yellows detected in paintings from a: $1838-1900$ period; b: $1901-1938$ period: Naples yellow $(\mathrm{Pb}, \mathrm{Sb})$, modified Naples yellow ( $\mathrm{Pb}, \mathrm{Sb}, \mathrm{Zn}, \mathrm{Sn}$ ), chromium yellow ( $\mathrm{Pb}, \mathrm{Cr}$ ), zinc chromate yellow ( $\mathrm{Zn}, \mathrm{Cr}$ ), barium chromate yellow $(\mathrm{Ba}, \mathrm{Cr}$ ), strontium yellow $(\mathrm{Sr}, \mathrm{Cr})$, cadmium yellow $(\mathrm{Cd})$, cadmium yellow modified with $\mathrm{ZnO}$ or $\mathrm{ZnS}$ additions (Cd, $\mathrm{Zn})$, cadmium yellow containing zinc and aluminum based admixtures ( $\mathrm{Cd}, \mathrm{Zn}, \mathrm{Al})$.

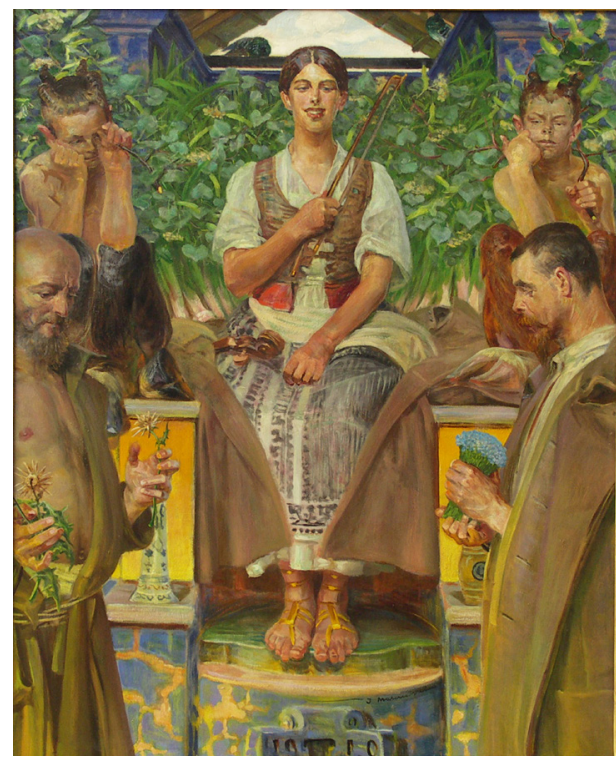

Fig. 5. Jacek Malczewski, For the Art and the Muse, 1910, District Museum in Toruń, Photo by M. Wachowiak.

However, there is a question concerning the source of the mentioned elements. On one painting, at least two kinds of cadmium yellow can be found, and these elements as well as amount of zinc in ratio to cadmium

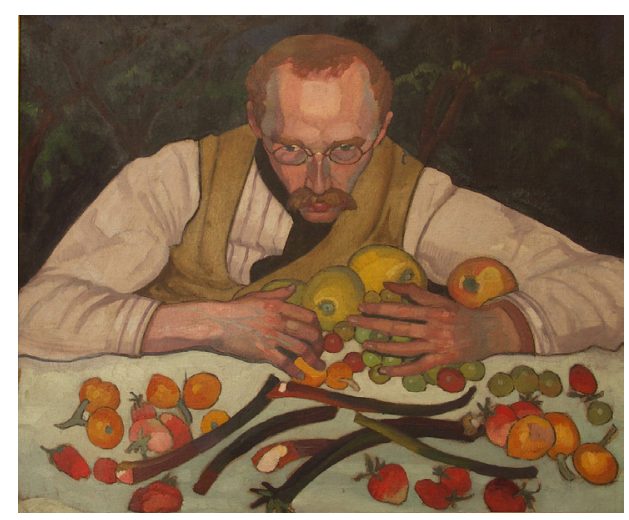

Fig. 6. Stanisław I. Witkiewicz, Portrait of dr Ignacy Wasserberg, about 1905-10, District Museum Toruń, Photo by M. Wachowiak.

added can support differentiation of cadmium yellows, as in the case of Malczewski's painting from 1910, where there is light lemon kind and intensive deep "egg-yolklike colour" cadmium yellow (Fig. 7a). In the latter pigment amount of potassium and aluminium is significant (Fig. 7b). Aluminium as admixture to the cadmium yellow appears at the end of the $19^{\text {th }}$ century and its ratio to the rest elements is growing with time. 

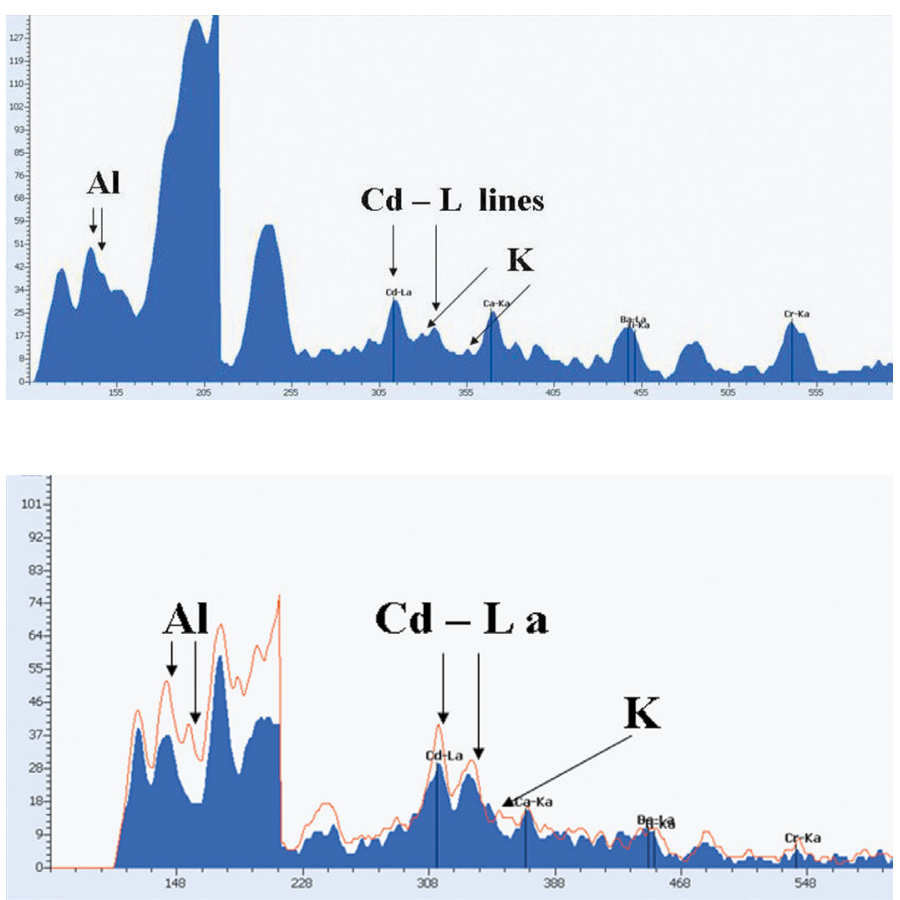

Fig. 7a. Fragment of XRF spectrum of cadmium yellow identified on Portrait of dr Ignacy Wasserberg by Stanisław I. Witkiewicz, containing additionally aluminium and potassium, and average amount of zinc as addition to the cadmium sulphide.

Fig. 7b. Fragment of XRF spectrum of cadmium yellow identified on painting For the Art and the Muse by Jacek Malczewski. Two kinds of cadmium yellows - light and dark - identified, one with majority of $\mathrm{Zn}$ and $\mathrm{Cd}$ (blue spectrum), the other with significant amounts of $\mathrm{Al}$ and $\mathrm{K}$, and minor amount of $\mathrm{Zn}$ (red line spectrum).
Whether this is alum - aluminium potassium sulphate or some other substance is still to be examined.

Another group of yellows are the factory-made mixtures of chromates and cadmium sulfides both of cadmium and chromium yellow and mixture of cadmium and strontium yellow, which are becoming common in the eighties of the $19^{\text {th }}$ century. Traditional Naples yellow, lead antimonite, is common in the first half of the $19^{\text {th }}$ century [18]. In the second half of the century, it is rather rare in traditional form, yet from the seventies on, there appear modified kinds containing zinc, tin and sometimes other compounds like aluminum, potassium, iron, copper and calcium in minor amounts [19]. According to different methods of production, they created various complex oxalate compounds in different ratios. In the case of Matejko, who was using them in extremely great amount, individual kinds are traceable on the painting when applied in pure impastos, basing on ratios of main elements and additionally recognized by characteristic ones represented in lesser amounts [20].

Seen as a whole, yellows are represented by chromium yellow and Naples yellow nearly throughout the whole $19^{\text {th }}$ century. In the sixties, there appear cadmium yellow which becomes popular in the seventies, and in the eighties its popularity is still raising. Zinc and strontium yellow occur much later than the date of their discovery. From the seventies on, modified Naples modern yellow is identified on paintings (Fig. 4a).

In the $20^{\text {th }}$ century, cadmium yellow is still common, there are some individual examples of the use of zinc yellow and in the case of cadmium yellow the kind containing aluminium is dominating (Fig. 7b). 


\subsection{Greens}

In the case of greens, there are a lot of difficulties in the accurate distinguishing of individual kinds as the main element chromium - is present in viridian, chromium oxide and greens from the group of variety of compositions based on mixtures of various yellows and blues.

For this reason, the XRF results are not conclusive. Further research was conducted using Raman spectroscopy to indentify exact greens (Figs. 8a, b).

Only in one case the chromium oxide green was identified with certainty. Yet it is possible that it was present on bigger number of paintings. Other chromium based green is viridian and comparable in frequency of occurrence - commercially available mixtures of yellow and blue greens. In their case, these with addition of cadmium yellow have appeared since the eighties of the $19^{\text {th }}$ century.

The copper based greens are less problematic in identification as most often it is the emerald green and the presence of arsenic that is distinctive. As the Scheeles green is

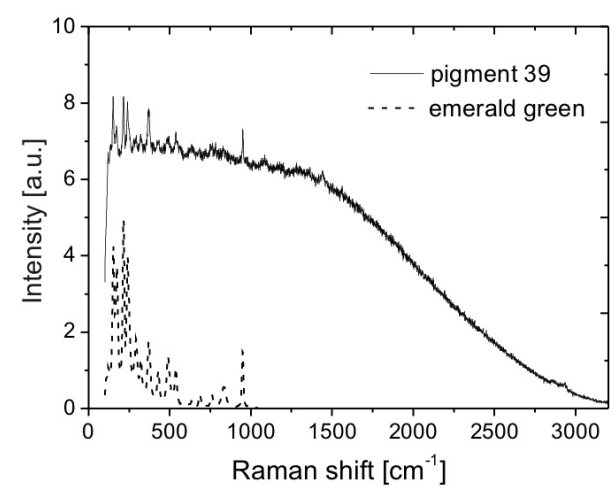

Fig. 8a. Raman spectrum of emerald green of Jan Matejko paint - paint tube sample from the collection of artist's materials from National Museum in Kraków. rather dull and declining in use in the second half of the century [21], there were hardly any examples from the first half of the $19^{\text {th }}$ century, so it could be concluded that most probable in all the cases was the emerald green, presence of which was confirmed with the Raman spectroscopy. Copper based green containing no arsenic is most probably the green verditer - synthetic version of malachite, suggested by comparisons of Raman spectra from available databases. Cobalt green is rare and was detected for the first time on the painting from 1883 .

Emerald green became popular in the seventies even though some early exceptional use was confirmed in 1845. Also in the case of viridian there was an exceptional isolated example of early use in 1839 and two later waves of popularity: first one in the early sixties and the second since the seventies, when it became to be common in use (Fig. 9a).

In the $20^{\text {th }}$ century, emerald green is less common. Although it continuously appears, it gives its place to viridian. There are hardly any copper based greens apart from copper/ arsenic emerald green and the cobalt green remains rare (Fig 9b).

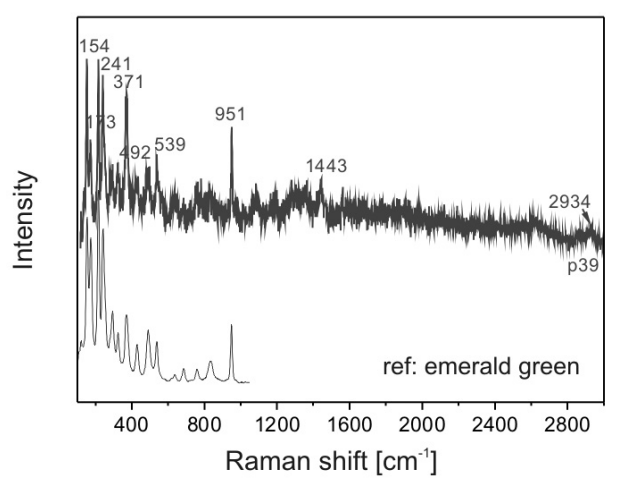

Fig. 8b. Raman spectrum of viridian from the J. Matejko paint - paint tube sample from the collection of artist's materials from National Museum in Kraków. 

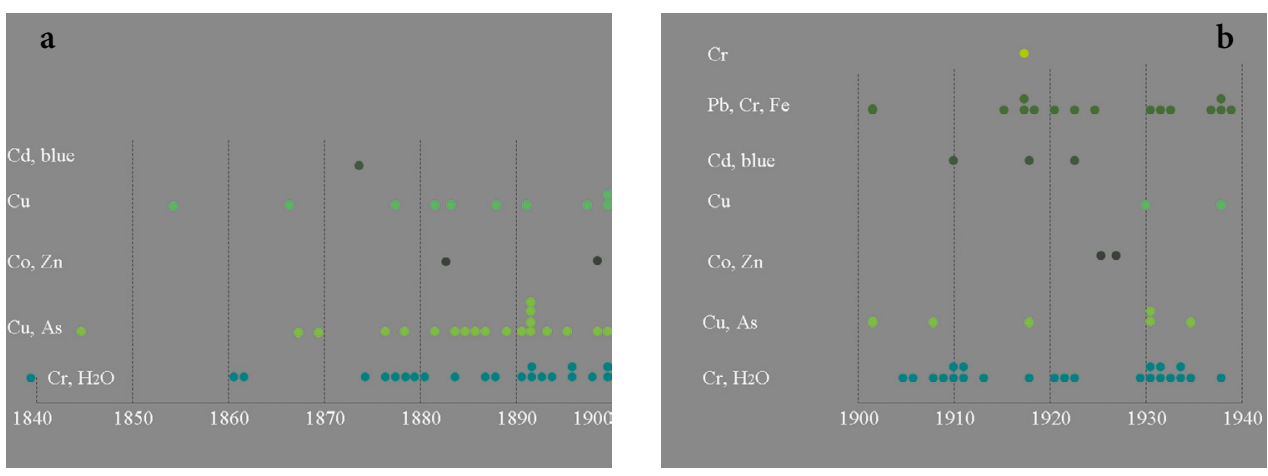

Fig. 9 Greens detected in paintings from a: $1838-1900$ period; b: $1901-1938$ period: viridian $\left(\mathrm{Cr}, \mathrm{H}_{2} \mathrm{O}\right)$, chromium oxide green $(\mathrm{Cr})$, copper based synthetic green (green verditer) $(\mathrm{Cu})$, emerald green $(\mathrm{Cu}, \mathrm{As})$, cobalt green $(\mathrm{Co}, \mathrm{Zn})$, composite green based on chrome yellow and Prussian blue $(\mathrm{Pb}, \mathrm{Cr}, \mathrm{Fe})$, composite yellow containing cadmium yellow and various kinds of blue (Cd, blue).

\subsection{Primings}

Whites being extenders in the grounds often occur in similar dates to the ones used in paint layers, yet in some cases they are introduced later. Until about half of the $19^{\text {th }}$ century most common are two-layered primings with iron based earth pigments in the bottom layers and lead white as the top one. Since approximately 1855 , when the significant additions of zinc white are identified in paints, they are also to be found in primings. Barites are found much later than in paints, as they have been detected in grounds since 1874. Lithopone is found in grounds in analogical time as in paints - in the late nineties. There are only two pure zinc white based grounds found till this moment in the $19^{\text {th }}$ century and these are artist self-applied primings by Podkowiński in 1894. Interestingly enough, after some time of diminished amounts of lead white detected only in complex mixtures, it returns as relatively pure individual main ingredient of primings in the nineties [22].

In the $20^{\text {th }}$ century, lead white is still quite common; however, more popular is its mix- ture with a significant amount of zinc white [23]. Another mixture that has appeared since about 1912 is the zinc white in majority with a slight addition of lead white. White fillers of the $20^{\text {th }}$ century primings when compared to pigments identified in paint layers show even greater popularity of zinc white with tiny admixture of lead. Pure zinc white grounds become popular similarly to the pigments in the thirties. No titanium is found in the priming in the period. Another issues are self-made and applied by artists' primings containing mostly chalk.

\subsection{Artists}

\section{Jan Matejko}

As individual painters' works have been investigated in a significant number, some further conclusions can be drawn. More than 60 paintings of Jan Matejko from the period $1852-1893$ have been analysed. From the very beginning, lead white and chromium yellow are present as well as cobalt blue. Soon after emerald green is introduced, other copper green broadens the palette in 1864. In 1869, four different pigments are implemented: 
cadmium yellow, zinc chromate yellow, viridian and zinc white - the latter exceptionally used as the lead white is the main white in all other years (Fig. 10). It seems that in 1869 is an extremely rich variety of pigments used. There are three kinds of chromate yellows neighboured with the cadmium yellow, emerald green and viridian, ultramarine

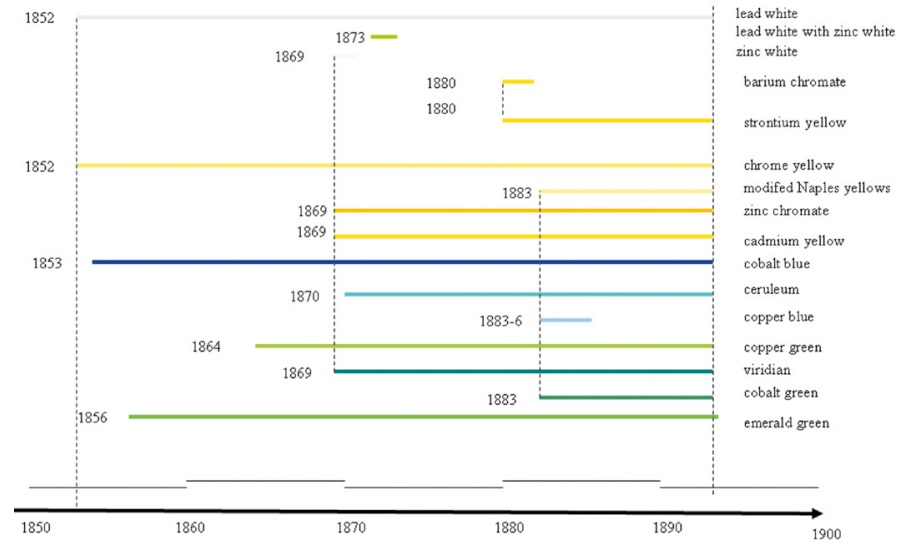

Fig. 10. Timelines of use of various pigment by Jan Matejko. Turning points of the same year of introduction of more than one pigment probably indicate moments of significant purchases of bigger number of painting materials. a big purchase of pigments was done. Next year, cerulean blue is found. Only for a short period, copper blue is used - just between the years 1883-1886. Additionally, in 1883, modified Naples yellow and cobalt green are introduced. Another result supportive in attribution, is the extremely wide use by Matejko of zinc and tin-modified modern Naples yellows, as well as of commercially available factory-prepared flash tone mixtures. Next characteristic detail of Matejko's technique is hardly any use of vermillion. A great variety of iron based reds is used instead of this red and the van Dyck brown in the underpainting.

\section{Józef Pankiewicz}

Pankiewicz is an artist who totally changed his style a few times, so it is really interesting to follow his stylistic changes and examine whether they were accompanied by the material ones. In the realistic period of his work, as in the painting The vegetable market (1888) from the National Museum in Poznań, there and cobalt blue as well as tiny amounts of cerulean and at least two different kinds of organic reds apart from the vermillion. Main white is the lead white; however, he could use zinc white as well.

In his impressionistic period 1890-1892, the palette is slightly narrowed, and the main white for the impastos rich landscape compositions is the lead white. There are less chromate yellows, cadmium yellow starts to dominate instead. Emerald green and viridian are widely used, accompanied by cobalt blue. There are hardly any black or earth iron based pigments. Priming is self-made, probably of gypsum.

The year 1983, in which Pankiewicz turns to symbolism, brings a lot of dark tones in his palette, which were absent in the impressionistic period. As the paintings are blurred and softly toned, more transparent zinc white surpasses lead white and there are hardly any blues on the palette.

Another turning into postimpressionistic period in 1907-1908 brings the rich color 
palette back. One of the new pigments introduced since 1911 is cobalt arsenate violet. Since 1911-1912 complex mixtures of chromate yellow containing greens have excluded emerald green and viridian. These greens return in the so-called Spanish period in the years 1915-1919, together with widely used cobalt arsenate violets, organic red precipitated on tin compounds, and since 1918 cadmium red has been implemented as well.

In the twenties of the $20^{\text {th }}$ century, after his return to Paris, Pankiewicz introduces cobalt greens apart from still used cadmium red. The late twenties and thirties is the mature period of the return of classical rules and a wide use of ochre's and umbers. In 1934, synthetic intensive rouge is found for the first time, and in 1938 Pankiewicz implements white admixed with titanium dioxide.

\section{Other artists}

In the seventies of the $19^{\text {th }}$ century, Józef Chełmoński used mainly a mixture of zinc white and lead white as a white colour and in the nineties - a mixture of zinc white, lead white and barium white, showing characteristic, distinguishable stable ratio of elements to each other. Additionally, these paintings from the nineties were executed on the same kind two layered priming containing lithopone.

Some rarely used pigments can be characteristic for individual painters as synthetic cobalt violets - arsenates and phosphates for Jacek Malczewski. Since 1894 he had been using cobalt arsenate in The Melancholy and a year later in The Circle (both from National Museum in Poznań). Other Polish artists started to use them about a decade later. Soon after, Malczewski introduced also manganese violet [24-26].

\section{Conclusions}

The study confirmed that written sources describing patents or dates of first examples of mass production are not consistent with the dates of real implementation onto paintings. In many cases a shift in time proves to be significant. Statistical overview enabled to draw a chronological panorama of the dates of the first appearance of exact pigments but also their raise in popularity of use and the decline or absence on some artists' palettes. There were also some examples of evolution of individual pigment as the case of cadmium yellow and especially of often complex compositions of whites. The latter, when identification is combined with the information on composition of primings, can be a supportive tool for dating, authentication and attribution (as in the case of Chełmoński works dated at the nineties of the $19^{\text {th }}$ century). Some individual characteristic choices can be traced as well. The core of the project was also the confirmation of reliability and accuracy of the portable XRF spectrometry when used for examination of numerous places of composition and related to the statistically significant number of investigated paintings of certain origin. Non-invasive recognition of paint layer pigment and primings fillers proved to be powerful, useful, effective, relatively simple, and cheap method which should be implemented into the museum's research kit and auction market practice in the preliminary examination of the painted works of art. The method is effective for dating in the periods of various introductions of new pigments. For that reason, the examination of the works from the $19^{\text {th }}$ and the first half of the $20^{\text {th }}$ century proves to be reasonable.

In many cases, it was the Raman spectroscopy resulting with conclusive identification 
and SEM-EDX to obtain the information on stratigraphy, important for proper interpretation of the XRF based results.

It is still a matter of question and a need for further research to situate Polish artists palettes' choice on a wider background of European art. From the sources and preserved paint tubes, it is known that most of painting material originated from abroad: Germany, Austria, France, England and Holland. When comparing to deeply analysed painters like impressionists or Van Gogh it seems that there was no significant delay in the use of newly introduced pigments, especially in the second half of the $19^{\text {th }}$ century.

Cerulean blue found in 1869 confirms a very early use of the pigment, as it is in the case of widely exploited cadmium yellows since the seventies of the $19^{\text {th }}$ century. More detailed comparisons and conclusions have to wait for further research on greater number both of western and central Europe artists' paintings from the $19^{\text {th }}$ and the first half of the $20^{\text {th }}$ century.

\section{Acknowledgements}

The authors would like to express their profound gratitude to the National Centre for Science, Poland, for approving founding for the project 2012/05/D/ HS2/03385, New Pigments of the $19^{\text {th }}$ century.

Special thanks to Anna Kroplewska from the District Museum in Torun for the possibility of the broadened research on the $20^{\text {th }}$ century paintings.

\section{References}

[1] M. Wachowiak, "New synthetic pigments of the $19^{\text {th }}$ and $20^{\text {th }}$ century", in: D. Markowski, S.Kamiński, M. Wachowiak (Eds.), Issues of Conservation and Restoration of Modern and Contemporary Art, Wydawnictwo Naukowe UMK, Toruń 2010, pp. 65-128.
[2] Ch.W. Mc Glinchey, "Handheld XRF for the examination of paintings: proper use and limitations", in: A.N. Shugar, J.L. Mass (Ed.), Handheld XRF for Art. Archaeology, Leuven University Press, 2013.

[3] M. Wachowiak, M. Sawczak, „Nieinwazyjna metoda identyfikacji pigmentów in situ - badania przenośnym spektroskopem XRF obrazów olejnych Józefa Pankiewicza", AUNC Zabytkoznawstwo i Konserwatorstwo, 39 (2010), pp. 15-37, http://apcz. umk.pl/czasopisma/index.php/AUNC_ZiK/article/ download/AUNC_ZiK.2010.007/2017 (accessed 10.07.2017)

[4] B. Haaf, „Industriell vorgrundierte Mallienen: Beitrage zur Entwicklungs-, Handels- und Materialgeschichte", Zeitschrift für Kunsttechnologie und Konservierung, 1/1987 Heft 2.

[5] M. Witlox, L. Carlyle, "A perfect ground is the very soul of the art': ground recipes for oil painting, 1600-1900", in: I. Verger (Ed.), ICOM-CC $14^{\text {th }}$ Triennial Meeting Preprints, London, James \&James, 2011, pp. 519-528.

[6] Ester S.B. Ferreira, R. Morrison, J. Boon, "Imaging chemical characterization of preparatory layers in fifteenth and sixteenth-century paintings", in: J.H. Townsend, T. Doherty, G. Heydenreich, J. Ridge (Eds.), Preparation for Painting. The artist's choice and its consequences, Archetype London 2008, pp. 52-58, ISBN: 9781904982326.

[7] F. Rosi, C. Miliani, I. Borgia, B. Brunetti and A. Sgamellotti, "Identification of nineteenth century blue and green pigments by in situ X-ray fluorescence and micro-Raman spectroscopy", Journal of Raman Spectroscopy, (2004) 35 610-615, DOI: 10.1002/ jrs. 1180 .

[8] Database of spectra of minerals, Department of Geosciences University of Arizona, http://rruff.info

[9] Infrared \& Raman Sers Group; http://www.irug. org

[10] Spectral Database for Organic Compounds, SDBS, National Institute of Advanced Industrial Science and Technology (AIST), Japan; http://sdbs. db.aist.go.jp

[11] M. Breitman, S. Ruiz-Moreno, A. Lopez-Gil, "Experimental problems in Raman spectroscopy applied to pigment identification in mixtures", 
Spectrochimica Acta A, (2007) 68 1114-1119, DOI: 10.1016/j.saa.2007.06.042.

[12] M. Wachowiak, A. Klisińska-Kopacz, "Issues of Jan Matejko painting technique", in: Interdisciplinary Research on the Works of Art, Justyna Olszewska-Świetlik, Joanna Arszyńska, Bożena Szmelter-Fausek (Eds.), Wydawnictwo Naukowe UMK, Toruń 2012, pp. 245-262.

[13] M. Wachowiak, Malarstwo olejne Józefa Pankiewicza - materiat i technika, $\mathrm{PhD}$ dissertation, Toruń 2008, manuscript.

[14] R.L. Feller, "Barium Sulfate - Natural and Synthetic", in: Robert L. Feller (Ed.), Artist's Pigments, A Handbook of Their History and Characteristics, Vol. 1, National Gallery of Art, Washington, Archetype Publications Ltd, London 2012, p. 49.

[15] M. Laver, Titanium dioxide whites, in: E. West Fitzgugh (Ed.), Artist's Pigments, A Handbook of Their History and Characteristics, Vol. 3, Archetype Publications Ltd, London 2012, p. 298.

[16] A.R. Burnstock, Ch. Jones, G. Cressey, "Characterisation of artists' chromium based yellow pigments", in: Zeitschrift für Kunsttechnologie und Konservierung, (2003) 17 , pp. 74-84.

[17] E. West Fitzgugh (Ed.), Artist's Pigments, A Handbook of Their History and Characteristics, Vol. 3, Archetype Publications Ltd, London 2012.

[18] J. Dik, F. Tichelaar, K. Goubitz, R. Peschar,

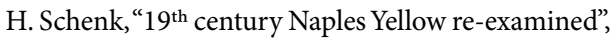
Zeitschrift für Kunsttechnologie und Konservierung, 16 (2002), 291-306.

[19] C. Sandalinas, S. Ruiz-Moreno, A. Lopez-Gil, Judith Miralles, "Experimental confirmation by Raman spectroscopy of a $\mathrm{Pb}$-Sn-Sb triple oxide yellow pigment in sixteenth-century Italian pottery", Journal of Raman Spectroscopy, 37 (2006), 1146-1153, DOI: 10.1002/jrs.1580.
[20] I. Żmuda-Trzebiatowska, M. Wachowiak, A. Klisińska-Kopacz, G. Trykowski, G. Śliwiński, Raman spectroscopic signatures of the yellow and ochre paints from artist palette of J. Matejko (1838-1893), Spectrochimica Acta, 136, (2015) 793-801, DOI: 10.1016/j.saa.2014.09.096.

[21] I. Fiedler, M.A. Bayard, "Emerald green and Scheele's green", in: Elisabeth West FitzHugh (Ed.), Artists' Pigments, A Handbook of their History and Characteristics, Vol. 3, Archetype London 1997, pp. 219-272.

[22] J. Salvant, M. Geldof, E. Ravaud, L. Megens, Ch. Walbert, M. Menu, Don. H. Johnson, "Investigation of the grounds of Tasset et L'hote commercially primed canvas used by Van Gogh in the period 1888 to 1890 , in: M. Vellekoop, M. Gedldof, E. Hendricks, L. Jansen, A. de Tagle (Ed.), Van Gogh's Studio Practice, Mercatorfonds, Brussels 2013, pp. 192-201.

[23] S. Morgan, J.H. Townsend, S.Hackney, R. Perry, "Canvas and its preparation in early twentieth century British paintings", in: J.H. Townsend, T. Doherty, G. Heydenreich, J. Ridge (Ed.), Preparation for Painting. The artist's choice and its consequences, Archetype Publications Ltd., London 2008, pp. 132-140.

[24] B. Fruhmann, M. Schreiner, M. Mantler, „Anorganische historische Pigmente einer Pigmentsammlung in Wien: Identifizierung zur Erstellung einer Datenbank", in: Zeitschrift für Kunsttechnologie und Konservierung, 17 (2003), 297-298.

[25] E.B.F. Pey, "The Hafkenscheid Collection", Maltechnik-Restauro, 93 (1987) 23-33; E.B.F. Pey, "The Organic Pigments of the Hafkenscheid Collection", Maltechnik-Restauro, 95 (1989), 146-150.

[26] E.L. Richter, H. Härlin, "A nineteenth century collection of pigments and painting materials", Studies in Conservation, 19 (1974), 76-82. 